\title{
Breast cancer histology and receptor status characterization in Asian Indian and Pakistani women in the U.S. - a SEER analysis
}

\author{
Madhuri Kakarala*1,2, Laura Rozek³, Michele Cote³, Samadhi Liyanage1 and Dean E Brenner1,2,4
}

\begin{abstract}
Background: Recent reports suggest increase in estrogen receptor (ER), progesterone receptor (PR) negative breast cancer yet little is known about histology or receptor status of breast cancer in Indian/Pakistani women.in the U.S.

Methods: We examined the United States National Cancer Institute's Surveillance Epidemiology and End Results (SEER) Cancer program to assess: a) frequency of breast cancer by age, b) histologic subtypes, c) receptor status of breast cancer and, d) survival in Indians/Pakistanis compared to Caucasians. There were 360,933 breast cancer cases diagnosed 1988-2006. Chi-Square analyses and Cox proportional hazards models, to estimate relative risks for breast cancer mortality after adjusting for confounders, were performed using Statistical Analysis Software 9.2.

Results: Among Asian Indian/Pakistani breast cancer patients, $16.2 \%$ were $<40 \mathrm{yrs}$. old compared to $6.23 \%$ in Caucasians ( $p<0.0001)$. Asian Indian women had more invasive ductal carcinoma (69.1 vs. 65.7\%, $p<0.0001)$, inflammatory cancer ( $1.4 \%$ vs. $0.8, p<0.0001)$ and less invasive lobular carcinoma $(4.2 \%$ vs. $8.1 \%, p<0.0001)$ than Caucasians. Asian Indian/Pakistani women had more ER/PR negative breast cancer (30.6\% vs. 21.8\%, $p=0.0095$ ) than Caucasians. Adjusting for stage at diagnosis, age, tumor grade, nodal status, and histology, Asian Indian/Pakistani women's survival was similar to Caucasians, while African Americans' was worse.

Conclusions: Asian Indian/Pakistani women have higher frequency of breast cancer (particularly in age < 40), ER/PR negative invasive ductal and inflammatory cancer than Caucasians.
\end{abstract}

\section{Background}

Breast cancer is the most frequently diagnosed cancer in females in the United States, affecting 1 in 8 women [1]. Worldwide, the incidence of breast cancer varies from 3.9/100,000 in Mozambique to as high as 101.1/100,000 in the U.S [2-5]. Geographic variation in breast cancer incidence can be attributed to racial and genetic differences, cultural differences, as well as environmental exposures that vary throughout the world $[5,6]$. Recent profiling work demonstrates that breast cancer is not one homogenous disease but consists of at least 5 distinct molecular subtypes with different treatment options and prognoses [7-12].

\footnotetext{
* Correspondence: mkakaral@umich.edu

1 Division of Hematology/Oncolog, Department of Internal Medicine, University of Michigan, 2150 Cancer Center, 1500 E Medical Center Drive, Ann Arbor, MI 48109-5390, USA

Full list of author information is available at the end of the article
}

Overall incidence of breast cancer is declining in the United States in the last decade $[6,13]$. However, the incidence of the biologically aggressive estrogen receptor (ER) negative, progesterone receptor (PR) negative breast cancer in women younger than 40 has been increasing in African Americans in the U.S., Nigerian, Chinese, Vietnamese, and Taiwanese populations [14-16]. Recent reports from India and Pakistan suggest an important increase in the incidence of breast cancer and specifically ER, PR negative breast cancer among these populations [16-19]. ER, PR negative breast cancer, of which $50 \%$ is also Her2Neu receptor negative (triple negative), is biologically aggressive, resistant to conventional cytotoxic chemotherapy treatment, and is associated with reduced survival compared to other subtypes of breast cancer [2023]

Cancer incidence studies in Asian Indians and Pakistanis in India and Pakistan as well as emigrants to vari- 
ous countries including Canada, United States, Singapore, United Kingdom have documented a rise in breast cancer in premenopausal Indian and Pakistani women (younger than 40) compared to local Caucasian women [24-33]. Yet very little is known about the specific histologic subtypes or receptor status of breast cancer in women of Indian/Pakistani origin in the U.S. [34-38]. Understanding frequency of occurrence of specific breast cancer subtypes and associated risk factors in Indians/ Pakistanis may elucidate breast cancer prevention, screening and treatment strategies tailored to the unique risk of this ethnic group.

We, therefore, explored whether analysis of United States National Cancer Institute's Surveillance Epidemiology and End Results (SEER) Program would: a) indicate a disproportionately high frequency of occurrence of breast cancer in Asian Indian/Pakistani women younger than 40 yrs (premenopausal age) compared to Caucasian females, b) provide data on specific histologic subtypes of breast cancer (eg. invasive ductal, inflammatory or lobular carcinoma), and c) molecular subtypes of breast cancer by receptor status in Asian Indian and Pakistani women in the United States and, 4) the impact of these subtypes on breast cancer specific survival. In this exploratory analysis, we examined demographic characteristics such as age and marital status and biological variables such as histology, estrogen and progesterone receptor status and in situ versus invasive disease as predictive variables for disease outcome and survival.

\section{Methods}

Subjects were 360,933 females, identified as Caucasian, African American, Hispanic or Indian/Pakistani, diagnosed with breast cancer between 1988 and 2006. Information regarding these subjects was obtained from the population-based SEER database in a case listing session. The SEER program collects information about all incident cancer cases including patient demographics, tumor site, stage at diagnosis, first course of treatment and annual follow up for vital status (SEER website: http:// seer.cancer.gov/about/). Currently, 18 population-based registries cover $26 \%$ of the United States population. Overall, the combined registries are comparable to the rest of the United States population with regard to poverty and education levels, but are slightly more urban and contain a higher proportion of foreign-born individuals. For the purposes of this analysis, data from 6 SEER sites with high proportion of Indian/Pakistani women were used. These 6 sites are: Atlanta--Georgia, Connecticut, California (Los Angeles, San Francisco-Oakland, San Jose-Monterey, and greater California), Metropolitan Detroit--Michigan, New Jersey, and Seattle-Puget Sound-Washington. In the SEER database, histological type of tumor is coded using International Classification of Dis- eases for Oncology, Third Edition (ICD-O) codes. The corresponding ICD-O morphology codes for breast cancers (Site and Morphology code = 'Breast') were selected: 8530 (inflammatory), 8522-8524 (mixed), 8100, 8500, 8501, 8503, 8521 and 8523 (ductal), and 8520 (lobular). Two behavior codes were also selected: 2 (in situ) and 3 (invasive). For the purposes of this analysis, a categorical variable was created, with categories for each histological type and behavior. Variables of interest included age at diagnosis, marital status, registry site, AJCC stage, tumor markers (ER and PR), vital status and survival time (months). Population denominators were not available for the Indian/Pakistani population in SEER or in United States Census data, so these results represent frequencies, not rates. As these data are de-identified, human investigation approval was not necessary for this project, but all investigators have signed limited-use data agreements to access and analyze SEER data.

\section{Statistical Methods}

Bivariate analyses (PROC FREQ) and multinomial analyses (PROC CATMOD) were implemented using Statistical Analysis Software (SAS) version 9.2. The p-values presented represent comparisons between Caucasian and Indian/Pakistani breast cancer patients. Bivariate analyses compared categorical age at diagnosis, marital status and SEER program site by race. Multinomial analyses compared clinical characteristics (histology, AJCC SEER modified stage, grade, ER/PR status, tumor size and nodal status) by race adjusting for age and SEER program site. For age, we assigned three age categories: age $<40$ yrs corresponding to premenopausal, age 40-50 yrs. for perimenopausal and age $>50$ for post menopausal age groups. These are empirical groupings and not based upon hormone testing to establish menopausal status. Tumor size was categorized as $<1 \mathrm{~cm}, 1-4 \mathrm{~cm}$ and $>4$ $\mathrm{cm}$.

\section{Hormone Receptor Status Analysis}

Estrogen receptor was available for $50.5 \%$ and progesterone receptor status was available for $49.8 \%$ of all breast cancer cases, including in situ ductal or lobular carcinoma ( $\mathrm{n}=204)$, invasive ductal $(\mathrm{n}=817)$, invasive lobular $(\mathrm{n}=50)$ and inflammatory breast cancer $(\mathrm{n}=16)$ in Asian Indian/Pakistani females $(\mathrm{n}=1087)$. The proportion of missing data did not differ between Caucasian, Indian/ Pakistani, Hispanic and African-American breast cancer patients.

\section{Survival}

Data from all 6 SEER registries were used for survival analyses. We chose to analyze from 1988 forward because prior to 1988 Asian Indians and Pakistanis were identified only as "Other Asians". Cox proportional hazards models were used to estimate relative risks (RRs) and 95\% 
Table 1: Age at diagnosis, marital status and survival of women with breast cancer, 6 SEER program sites, 1988-2006, by ethnicity

\begin{tabular}{|c|c|c|c|c|c|}
\hline Variable & $\begin{array}{l}\text { Caucasian } \\
n=300,494\end{array}$ & $\begin{array}{l}\text { Indian/Pakistani } \\
n=1,350\end{array}$ & $\begin{array}{l}\text { African-American } \\
n=40,647\end{array}$ & $\begin{array}{l}\text { Hispanic } \\
n=18,442\end{array}$ & P value* \\
\hline Age category & & & & & $<0.0001$ \\
\hline Premenopausal (age < 40) & $18001(6.0)$ & $219(16.2)$ & 4405 (10.8) & $2026(11.0)$ & \\
\hline Perimenopausal (age 40-50) & $55597(18.5)$ & 403 (29.9) & $9401(23.1)$ & $4536(24.6)$ & \\
\hline Postmenopausal (age > 50) & $226896(75.5)$ & $728(53.9)$ & $26841(66.0)$ & $11880(64.4)$ & \\
\hline Marital Status & & & & & $<0.0001$ \\
\hline Single & $33145(11.0)$ & $92(6.8)$ & $9528(23.4)$ & $3080(16.7)$ & \\
\hline Married & $166927(55.6)$ & $1005(74.4)$ & $14537(35.8)$ & $9814(53.2)$ & \\
\hline Other & $100422(33.4)$ & $253(18.7)$ & $16582(40.8)$ & $5548(30.1)$ & \\
\hline SEER Program Site & & & & & $<0.0001$ \\
\hline San Franciso-Oakland & $44281(14.7)$ & $312(23.1)$ & $5129(12.6)$ & $3392(18.4)$ & \\
\hline Connecticut & $53693(17.9)$ & $136(10.1)$ & $3293(8.1)$ & $1743(9.5)$ & \\
\hline Metropolitan Detroit & $49462(16.5)$ & $141(10.4)$ & $12416(30.6)$ & $466(2.5)$ & \\
\hline Seattle (Puget Sound) & $54259(18.1)$ & $84(6.2)$ & $1378(3.4)$ & $476(2.6)$ & \\
\hline Metropolitan Atlanta & $23223(7.7)$ & $131(9.7)$ & $8547(21.0)$ & $467(2.5)$ & \\
\hline San Jose-Monterey & $18291(6.1)$ & $238(17.6)$ & $412(1.0)$ & $1679(9.1)$ & \\
\hline Los Angeles & $57285(19.1)$ & $308(22.8)$ & $9472(23.3)$ & $10219(55.4)$ & \\
\hline Mean Survival in Months (SD) & $67.0(53.7)$ & $48.0(46.2)$ & $53.0(52.7)$ & $56.0(49.5)$ & $<0.0001^{* *}$ \\
\hline
\end{tabular}

Confidence Intervals for mortality from breast cancer after adjusting for relevant confounders including AJCC SEER modified stage, histology, behavior, age at diagnosis and SEER program site. A minimum survival time of 2 months was used in selecting cases in order to exclude those diagnosed only at autopsy or those who may have died before pursuing treatment. Non Hispanic Caucasians served as the reference group for relative risk comparisons. All tests were two tailed and $\mathrm{p}$ values $<0.05$ were considered statistically significant.

\section{Results}

Frequency of Breast Cancer in Asian Indians/Pakistanis

A total of 1350 cases of breast cancer cases among Asian Indian/Pakistani women were found in the SEER database from 6 SEER sites between 1988-2006. Among Asian Indian/Pakistani breast cancer patients, $16.2 \%$ were women younger than age 40 or premenopausal women compared to $6.23 \%$ in Caucasian women $(\mathrm{p}<0.0001)$ and $10.8 \%$ of African American and 11\% of Hispanic women as shown in Table 1. This higher percentage of women under age 40 with breast cancer diagnoses in Asian Indians/Pakistanis was also found in the perimenopausal 4050 yr olds as well with $29.9 \%$ of Asian Indians/Pakistanis compared to $18.9 \%$ of Caucasian women ( $\mathrm{p}<0.0001$ ). African American and Hispanic women between ages 4050 had intermediate frequency with $23.1 \%$ and $24.6 \%$ respectively. A correspondingly lower percentage of breast cancer was found in postmenopausal (age > 50 yrs.) Asian Indian/Pakistani women compared to Caucasians $(53.9 \%$ vs. $75.5 \%, \mathrm{p}<0.0001)$.

\section{Breast Cancer Stage at Diagnosis in Asian Indians/ Pakistanis}

Percentage of women diagnosed with stage IV or metastatic disease was similar in Asian Indians/Pakistanis compared to Caucasians (4.9 vs. 4.5\%). African American and Hispanic women had significantly higher percentage of women presenting with stage III (11.9\% and 9.6\% versus $7.0 \%, \mathrm{p}<0.01$ ) compared to Caucasian women. African American women also had the highest percent of 
Table 2: Histology and receptor status of breast cancer in women in the 6 SEER program sites diagnosed between 19882006 by ethnicity

\begin{tabular}{|c|c|c|c|c|c|}
\hline Variable & Caucasian & Indian/Pakistani & African-American & Hispanic & P value* \\
\hline Histology & & & & & $0.02^{*}$ \\
\hline In situ---Ductal & $31998(12.1)$ & $142(12.0)$ & 4409 (12.7) & 1907 (11.8) & \\
\hline In situ---Lobular & $6641(2.5)$ & $21(1.8)^{*}$ & $648(1.9)$ & $330(2.0)$ & \\
\hline In situ--Mixed & $6243(2.4)$ & $41(3.5)^{*}$ & $984(2.8)$ & $420(2.6)$ & \\
\hline Histology & & & & & $<0.0001^{*}$ \\
\hline Invasive---Ductal & $173174(65.6)$ & $817(69.1)^{*}$ & $24254(69.6)$ & $10858(67.3)$ & \\
\hline Invasive---Lobular & $21725(8.2)$ & $50(4.2)^{*}$ & $1752(5.0)$ & $1023(6.3)$ & \\
\hline Invasive--Mixed & $21853(8.3)$ & $96(8.1)$ & $2253(6.5)$ & $1322(8.2)$ & \\
\hline Inflammatory carcinoma & $2218(0.8)$ & $16(1.4)^{*}$ & $537(1.5)$ & $265(1.6)$ & \\
\hline Estrogen Receptor (ER) & & & & & $0.0688^{*}$ \\
\hline Positive & $130267(79.3)$ & $463(71.9)^{*}$ & $12902(62.6)$ & $6984(72.3)$ & \\
\hline Negative & $34040(20.8)$ & $181(28.1)^{*}$ & $7724(37.5)$ & $2673(27.7)$ & \\
\hline Progesterone Receptor (PR) & & & & & $0.0260^{*}$ \\
\hline Positive & $108451(68.2)$ & $391(62.2)^{*}$ & $10548(53.1)$ & $5758(62.5)$ & \\
\hline Negative & $50533(31.8)$ & $238(37.8)^{*}$ & $9315(46.9)$ & 3449 (37.5) & \\
\hline ER/PR & & & & & $0.0095^{*}$ \\
\hline Positive/Positive & 103767 (78.2) & $377(69.4)^{*}$ & 9702 (58.9) & $5408(70.3)$ & \\
\hline Negative/Negative & $28994(21.8)$ & $166(30.6)^{*}$ & $6772(41.1)$ & $2285(29.7)$ & \\
\hline
\end{tabular}

* $\mathrm{p}$ value is for comparison between Asian Indian/Pakistani and Caucasian women adjusted for age at diagnosis and SEER program

stage IV disease $(8.1 \%$ compared to $4.5 \%$ in Caucasians, $\mathrm{p}$ $<0.01)$.

\section{Breast Cancer Histology and Receptor Status in Asian Indians/Pakistanis}

The histologic subtypes of in situ lobular or mixed in situ cancer differed significantly between Asian Indian/Pakistani compared to Caucasian women, while in situ ductal cancer did not differ significantly as shown in Table 2 ( $\mathrm{p}=$ 0.02 ), however, given the large number of subjects the significance is not likely meaningful. Asian Indian women had a slightly higher frequency of invasive ductal carcinoma (69.1 vs. $65.6 \%, \mathrm{p}<0.0001)$ and lower invasive lobular carcinoma $(4.2 \%$ vs. $8.2 \%, \mathrm{p}<0.0001)$ compared to Caucasian women. Mixed histology tumors were of similar frequency of occurrence in both ethnic groups. Inflammatory breast cancer, which is a particularly aggressive subtype, was slightly higher in Asian Indian/ Pakistanis, African Americans and Hispanics compared to Caucasians $(1.4 \%, 1.5 \%, 1.6 \%$ respectively vs. $0.8 \%$, p < 0.0001). More Asian Indian/Pakistani women were diag- nosed at AJCC Seer Modified Stage II (47.5\% vs. 37.5\%, p $<0.001)$, III (11.3\% vs. $7.0 \%, \mathrm{p}<0.001)$ and a smaller percentage in stage I ( $36.3 \%$ vs. $51.0 \%, \mathrm{p}<0.001)$ compared to Caucasian women as shown in Table 3. There was higher percentage of estrogen and progesterone receptor negative breast cancer $(30.6 \%$ vs. $21.8 \%$, p $=0.0095)$ breast cancer in Asian Indian/Pakistani women compared to Caucasians (Table 2). Hispanics were similar to Asian Indians/Pakistanis in receptor negativity (29.7 vs. $30.6 \%$ ) but African Americans had the highest percentage of ER/PR negative disease $41 \%$ compared to $21.8 \%$ in Caucasians $(\mathrm{p}<0.0095)$. We explored marital status of breast cancer patients and found that a significantly greater percentage of Asian Indian/Pakistani than Caucasian breast cancer patients are married (74.4\% vs. $55.4 \%$, $\mathrm{p}<0.0001)$.

\section{Breast Cancer Specific Survival in Asian Indians/Pakistanis}

In order to better understand the correlates of survival in racial subgroups, we further examined this survival outcome in multivariate regression analysis using age at 
Table 3: Stage at diagnosis, tumor grade, primary tumor size and nodal status by ethnicity in 6 SEER program sites between 1988-2006.*

\begin{tabular}{|c|c|c|c|c|c|}
\hline Variable & Caucasian & Indian/Pakistani & African-American & Hispanic & Pvalue* \\
\hline AJCC stage & & & & & $<0.001$ \\
\hline Stage I & $118856(51.0)$ & $381(36.3)^{*}$ & 11187 (35.9) & $6069(41.9)$ & \\
\hline Stage II & $87267(37.5)$ & $499(47.5)^{*}$ & $13735(44.1)$ & $6322(43.7)$ & \\
\hline Stage III & $16236(7.0)$ & $119(11.3)^{*}$ & $3698(11.9)$ & 1394 (9.6) & \\
\hline Stage IV & $10619(4.5)$ & $51(4.9)$ & $2512(8.1)$ & $694(4.8)$ & \\
\hline Tumor Grade & & & & & $<0.0001$ \\
\hline 1 & $42232(19.0)$ & $150(13.5)^{*}$ & $3751(12.5)$ & $2191(15.0)$ & \\
\hline 2 & $93718(42.2)$ & $452(40.8)$ & $10376(34.6)$ & $5751(39.5)$ & \\
\hline 3 & $76391(34.4)$ & $465(41.9)^{*}$ & 14561 (48.6) & $5856(40.2)$ & \\
\hline 4 & $9607(4.3)$ & $42(3.8)$ & $1254(4.2)$ & $758(5.2)$ & \\
\hline Primary Tumor Size & & & & & 0.4432 \\
\hline$<1 \mathrm{~cm}$ & $8364(25.4)$ & $51(21.4)$ & $938(18.2)$ & $564(20.5)$ & \\
\hline $1--4 \mathrm{~cm}$ & $20748(62.9)$ & $151(63.5)$ & $3140(60.9)$ & $1758(64.0)$ & \\
\hline$>4 \mathrm{~cm}$ & 3887 (11.7) & $36(15.1)$ & $1079(20.9)$ & $425(15.5)$ & \\
\hline \# of nodes positive & & & & & 0.4668 \\
\hline 0 & $144518(68.6)$ & $597(59.5)$ & $16291(60.4)$ & $8459(63.1)$ & \\
\hline $1-3$ & $42546(20.2)$ & $236(23.5)$ & $6474(24.0)$ & $2979(22.2)$ & \\
\hline $4-9$ & $15256(7.2)$ & $111(11.1)$ & $2708(10.1)$ & $1242(9.3)$ & \\
\hline$>9$ & $8325(4.0)$ & $60(5.9)$ & $1481(5.5)$ & $718(5.4)$ & \\
\hline
\end{tabular}

* $\mathrm{p}$ value is for comparison between Asian Indian/Pakistani and Caucasian women adjusted for age at diagnosis and SEER program

diagnosis, AJCC SEER Modified Stage, and histologic subtype as predictors for survival (Table 4). Survival time was censored at five years. Estrogen/progesterone receptor status and nodal status were not used as their data were sparse in the younger age groups in minority populations. Women with inflammatory breast cancer were found to have a hazard ratio (HR) of 3.47 (CI: 2.48 - 4.86), increasing stage $\mathrm{HR}$ of 2.80 (CI: 2.63-2.98), African Americans HR of 1.59 (CI: 1.37-1.85), and older age group at diagnosis a HR of 2.0 (CI: 1.75-2.29) of not surviving to 5 years post diagnosis compared to Caucasian women. Once stage at diagnosis, age, and histologic profile were controlled for, the survival outcome of Asian Indian/Pakistani women did not differ significantly from Caucasians (HR $=0.45$, C.I. $=0.11-1.79)$ however, African American women had significantly worse survival than Caucasians.

\section{Discussion}

Asian Indians/Pakistanis are one of the fastest growing ethnic groups in the United States and have a higher fre- quency of breast cancer than Caucasians [26,33]. Our analysis of breast cancer diagnoses using the SEER database for cases diagnosed from 1988-2006 finds a disproportionately high occurrence rate of breast cancer in Asian Indian/Pakistani women younger than 40 yrs. compared to Caucasians. It is possible the overall age distribution of Asian Indian/Pakistani women is younger compared to the other racial/ethnic groups in the United States, resulting in a disproportionate breakdown by age. This could be due to immigration patterns, as the Indian population reflects the rapid increases in young immigrants in the latter half of the $20^{\text {th }}$ century. Unfortunately, immigration data were not available in SEER, but our results suggest the need for future studies to address this question. However, these findings are consistent with similar high rates observed among south Asians or Indians in Singapore, United Kingdom, Malaysia, Canada and in Indians in India [25,26,33,34,39-41]. We were unable to examine trends over time using the SEER program due to the relatively small number of cases diagnosed every year for Asian Indians and Pakistanis, however at least one 
Table 4: Disease-specific five- year survival using Cox-proportional hazards adjusted for SEER site

\begin{tabular}{|c|c|c|}
\hline Predictor & Univariate HR (95\% C.I.) & Multivariate model \\
\hline Stage & $3.08(2.905--3.26)$ & $2.80(2.63--2.98)$ \\
\hline Inflammatory & $5.41(5.12--5.71)$ & $3.47(2.48--4.86)$ \\
\hline Mixed & $0.73(0.70--0.77)$ & $0.95(0.70--1.28)$ \\
\hline Ductal & $1.03(1.00--1.06)$ & $1.43(1.13-1.80)$ \\
\hline Lobular & 1.00 (reference) & 1.00 (reference) \\
\hline African-American & $1.66(1.62--1.69)$ & $1.59(1.37--1.85)$ \\
\hline Hispanic & $0.95(0.91--0.99)$ & $0.72(0.52--0.98)$ \\
\hline Indian/Pakistani & $0.82(0.70--0.96)$ & $0.45(0.11--1.79)$ \\
\hline Caucasian & 1.00 (reference) & 1.00 (reference) \\
\hline Age group & $1.39(1.37--1.41)$ & $2.00(1.75--2.29)$ \\
\hline
\end{tabular}

study shows a rise in breast cancer incidence rates in Asian Indians over time [14].

Over the past decade, the biology of breast cancer has been redefined into groups of distinct biological subtypes. Each subtype presents with specific clinical, pathological and molecular phenotypes associated with diverse natural histories, therapeutic implications and prognoses [8,42-47]. Previously published studies of breast cancer in Asian Indians did not examine the frequency of specific histologic subtypes of breast cancer: invasive ductal, lobular and inflammatory carcinoma of the breast. Each of these subtypes has a different biologic behavior and prognosis $[11,48,49]$. Inflammatory breast cancer, for example, is the most aggressive histologic subtype with worse hazard ratio for 5 year survival in our own multivariate analysis [50-52] and occurs more frequently among Asian Indians compared to Caucasians in our analysis. Lobular invasive carcinoma may present with bilateral disease and recur many years from primary disease presentation. The most common histology in both Caucasians and Asian Indians/Pakistanis, invasive ductal carcinoma is usually unilateral and risk of recurrence decreases as time elapses from primary diagnosis $[49,53,54]$. Differences in behavior of distinct breast cancer histologies determine whether a patient receives breast conservation or aggressive surgical treatment, sentinel node or complete axillary dissection. Systemic treatment such as duration of hormone therapy, targeted therapy for Her2Neu positive dis- ease and followup patterns also differ for different breast cancer subtypes [55]. Our SEER analysis shows that invasive ductal carcinoma is more frequently diagnosed in Asian Indian/Pakistani women compared to Caucasian women while diagnosis of lobular carcinoma is correspondingly lower.

A higher proportion of breast cancer in Asian Indian/ Pakistani women compared to Caucasians $(30.6 \%$ vs. $21.8 \%, \mathrm{p}<0.0095)$ in the SEER database was ER and PR negative. It must be noted that individuals for whom receptor status was missing were excluded from that analysis and missing data was comparable in both groups. Reports in Asian Indians in India and the United Kingdom also document high rates of ER, PR negative breast cancer $[34,36]$. Interestingly, when receptor status was examined by age, we found that this difference was driven by increased percentage of ER/PR negative disease in 40$50 \mathrm{yr}$ olds and those older than 50 , rather than by younger aged women.

We were unable to examine Her2 Neu receptor status as this variable is only recently being collected by the SEER program. However, pathologic assessments of tumors over time have found the particularly aggressive, and least treatable, triple negative (ER, PR and Her2Neu negative) or basal breast cancer molecular subtype to be common in Asian Indians [38,56]. This subtype of breast cancer is more common among BRCA1 gene mutation carriers, however, known BRCA1 and BRCA2 mutations 
do not seem to explain the triple negative cancer in Indian women [57-59]. Stage at diagnosis is critical in breast cancer as early stage cancer is curable while more advanced stages are not $[28,60]$. Asian Indian/Pakistani women were diagnosed at significantly more advanced stages of breast cancer than Caucasian women suggesting a need to raise awareness of screening recommendations in this ethnic group

\section{Conclusion}

In conclusion, Asian Indian and Pakistani women in the US had more ER and PR negative tumors than their Caucasian counterparts. Invasive ductal carcinoma is the most common histology. Inflammatory cancer is also more common in Asian Indians/Pakistanis than Caucasians. Given the limited treatment options for receptor negative breast cancer and poor prognosis, it is important to encourage screening and early diagnosis measures such as annual clinical breast exams for these women.

\section{Competing interests}

The authors declare that they have no competing interests.

\section{Authors' contributions}

$M K, L R, M C S L$ and DB conceptualized this study, MK and LR conducted the analysis, MC extracted the SEER data and interpreted each variable, SL conducted background literature review and assisted with analysis, all authors wrote this manuscript and approved the final version.

\section{Author Details}

'Division of Hematology/Oncolog, Department of Internal Medicine, University of Michigan, 2150 Cancer Center, 1500 E Medical Center Drive, Ann Arbor, MI 48109-5390, USA, 2V.A. Medical Center, 2150 Cancer Center, 1500 E. Medical Center Dr., Ann Arbor, MI 48109-5390, USA, ${ }^{3}$ School of Public Health, Environmental Health Sciences, 6630 SPH 1, Ann Arbor, MI 48109-2029, USA and ${ }^{4}$ Department of Pharmacology, University of Michigan, 2150 Cancer Center, 1500 E Medical Center Drive, Ann Arbor, MI 48109-5390, USA

Received: 1 October 2009 Accepted: 11 May 2010

Published: 11 May 2010

\section{References}

1. Jemal A, Siegel R, Ward E, Hao Y, Xu J, Thun MJ: Cancer statistics, 2009. CA Cancer J Clin 2009, 59(4):225-249.

2. Bolufer P, Molina R, Ruiz A, Hernandez M, Vazquez C, Lluch A: Estradiol receptors in combination with neu or myc oncogene amplifications might define new subtypes of breast cancer. Clin Chim Acta 1994, 229(1-2):107-122.

3. La Vecchia C, Franceschi S, Lucchini F, Levi F: International Variations and Trends in the Incidence of Breast Cancer in Older Women. Cancer Control 1994, 1(4):327-333.

4. Marugame T, Katanoda K: International comparisons of cumulative risk of breast and prostate cancer, from cancer incidence in five continents Vol. VIII. Jpn J Clin Oncol 2006, 36(6):399-400.

5. Rosen M, Lundin A, Nystrom L, Rutqvist LE, Stenbeck M, Talback M: [Incidence and mortality of breast cancer during a 25-year period. International and regional comparisons]. Lakartidningen 2000, 97(4):294-299.

6. Morabia A, Costanza MC: Reproductive factors and incidence of breast cancer: an international ecological study. Soz Praventivmed 2000, 45(6):247-257.

7. Boyd ZS, Wu QJ, O'Brien C, Spoerke J, Savage H, Fielder PJ, Amler L, Yan Y, Lackner MR: Proteomic analysis of breast cancer molecular subtypes and biomarkers of response to targeted kinase inhibitors using reverse-phase protein microarrays. Mol Cancer Ther 2008, 7(12):3695-3706.

8. Carey LA, Perou CM, Livasy CA, Dressler LG, Cowan D, Conway K, Karaca G, Troester MA, Tse CK, Edmiston S, et al:: Race, breast cancer subtypes, and survival in the Carolina Breast Cancer Study. JAMA 2006, 295(21):2492-2502.

9. Cheang MC, Voduc D, Bajdik C, Leung S, McKinney S, Chia SK, Perou CM, Nielsen TO: Basal-like breast cancer defined by five biomarkers has superior prognostic value than triple-negative phenotype. Clin Cancer Res 2008, 14(5):1368-1376.

10. Onitilo AA, Engel JM, Greenlee RT, Mukesh BN: Breast cancer subtypes based on ER/PR and Her2 expression: comparison of clinicopathologic features and survival. Clin Med Res 2009, 7(1-2):4-13.

11. Sims AH, Howell A, Howell SJ, Clarke RB: Origins of breast cancer subtypes and therapeutic implications. Nat Clin Pract Oncol 2007, 4(9):516-525.

12. Sorlie T: Molecular portraits of breast cancer: tumour subtypes as distinct disease entities. Eur J Cancer 2004, 40(18):2667-2675.

13. Couris CM, Polazzi S, Olive F, Remontet L, Bossard N, Gomez F, Schott AM, Mitton N, Colonna M, Trombert B: Breast cancer incidence using administrative data: correction with sensitivity and specificity. $J$ Clin Epidemiol 2009, 62(6):660-666

14. Deapen D, Liu L, Perkins C, Bernstein L, Ross RK: Rapidly rising breast cancer incidence rates among Asian-American women. Int $\mathrm{J}$ Cancer 2002, 99(5):747-750.

15. Lee SY, Jeong SH, Kim YN, Kim J, Kang DR, Kim HC, Nam CM: Costeffective mammography screening in Korea: high incidence of breast cancer in young women. Cancer Sci 2009, 100(6):1105-1111.

16. Lin CH, Liau JY, Lu YS, Huang CS, Lee WC, Kuo KT, Shen YC, Kuo SH, Lan C, Liu JM, et al:: Molecular subtypes of breast cancer emerging in young women in Taiwan: evidence for more than just westernization as a reason for the disease in Asia. Cancer Epidemiol Biomarkers Prev 2009, 18(6):1807-1814.

17. Adebamowo CA, Famooto A, Ogundiran TO, Aniagwu T, Nkwodimmah C, Akang EE: Immunohistochemical and molecular subtypes of breast cancer in Nigeria. Breast Cancer Res Treat 2008, 110(1):183-188.

18. Ihemelandu CU, Leffall LD Jr, Dewitty RL, Naab TJ, Mezghebe HM, Makambi KH, Adams-Campbell L, Frederick WA: Molecular breast cancer subtypes in premenopausal and postmenopausal African-American women: age-specific prevalence and survival. J Surg Res 2007, 143(1):109-118

19. Nichols HB, Trentham-Dietz A, Love RR, Hampton JM, Hoang Anh PT, Allred DC, Mohsin SK, Newcomb PA: Differences in breast cancer risk factors by tumor marker subtypes among premenopausal Vietnamese and Chinese women. Cancer Epidemiol Biomarkers Prev 2005, 14(1):41-47.

20. Akiyama F, Iwase H: Triple negative breast cancer: clinicopathological characteristics and treatment strategies. Breast Cancer 2009, 16(4):252-3.

21. Alli E, Sharma VB, Sunderesakumar P, Ford JM: Defective repair of oxidative dna damage in triple-negative breast cancer confers sensitivity to inhibition of poly(ADP-ribose) polymerase. Cancer Res 2009, 69(8):3589-3596.

22. Bouchalova K, Cizkova M, Cwiertka K, Trojanec R, Hajduch M: Triple negative breast cancer--current status and prospective targeted treatment based on HER1 (EGFR), TOP2A and C-MYC gene assessment. Biomed Pap Med Fac Univ Palacky Olomouc Czech Repub 2009, 153(1):13-17.

23. Carey LA, Dees EC, Sawyer L, Gatti L, Moore DT, Collichio F, Ollila DW, Sartor Cl, Graham ML, Perou CM: The triple negative paradox: primary tumor chemosensitivity of breast cancer subtypes. Clin Cancer Res 2007, 13(8):2329-2334.

24. Gajalakshmi P, Natarajan TG, Selvi Rani D, Thangaraj K: A novel BRCA1 mutation in an Indian family with hereditary breast/ovarian cancer. Breast Cancer Res Treat 2007, 101(1):3-6.

25. Ghumare SS, Cunningham JE: Breast cancer trends in Indian residents and emigrants portend an emerging epidemic for India. Asian Pac $J$ Cancer Prev 2007, 8(4):507-512.

26. Goggins WB, Wong G: Cancer among Asian Indians/Pakistanis living in the United States: low incidence and generally above average survival. Cancer Causes Control 2009, 20(5):635-643.

27. Hebert JR, Ghumare SS, Gupta PC: Stage at diagnosis and relative differences in breast and prostate cancer incidence in India: 
comparison with the United States. Asian Pac J Cancer Prev 2006, 7(4):547-555

28. Jack RH, Davies EA, Moller H: Breast cancer incidence, stage, treatment and survival in ethnic groups in South East England. Br J Cancer 2009, 100(3):545-550

29. Kamath SK, Murillo G, Chatterton RT Jr, Hussain EA, Amin D, Mortillaro E, Peterson CT, Alekel DL: Breast cancer risk factors in two distinct ethnic groups: Indian and Pakistani vs. American premenopausal women. Nutr Cancer 1999, 35(1):16-26.

30. Murthy NS, Agarwal UK, Chaudhry K, Saxena S: A study on time trends in incidence of breast cancer - Indian scenario. Eur J Cancer Care (Engl) 2007, 16(2):185-186

31. Raju GC, Naraynsingh V: Breast cancer in West Indian women in Trinidad. Trop Geogr Med 1989, 41(3):257-260.

32. Rao R, Kuerer H, Cristofanilli M, Brigilio K, Shukla S, Rao M, Krishnamurthy S: Breast cancer in the asian Indian population of the United States: a call for screening and education. Breast J 2008, 14(4):402-403.

33. Rastogi T, Devesa S, Mangtani P, Mathew A, Cooper N, Kao R, Sinha R: Cancer incidence rates among South Asians in four geographic regions: India, Singapore, UK and US. Int J Epidemio/ 2008, 37(1):147-160.

34. Dey S, Boffetta P, Mathews A, Brennan P, Soliman A, Mathew A: Risk factors according to estrogen receptor status of breast cancer patients in Trivandrum, South India. Int J Cancer 2009, 125(7):1663-70.

35. Kumar VL, Srivastava A, Singhal R, Kumar V: Immunoreactive estrogen receptor in breast tumor and adjacent tissue: association with clinicopathological characteristics in Indian population. J Surg Oncol 2005, 89(4):251-255

36. Navani S, Bhaduri AS: High incidence of oestrogen receptor negative progesterone receptor positive phenotype in Indian breast cancer: fact or fiction? Indian J Pathol Microbiol 2005, 48(2):199-201.

37. Seshadri R, Shah PN: Steroid receptors in breast cancer in Indian women. Anticancer Res 1984, 4(6):403-407.

38. Shet T, Agrawal A, Nadkarni M, Palkar M, Havaldar R, Parmar V, Badwe R, Chinoy RF: Hormone receptors over the last 8 years in a cancer referral center in India: what was and what is? Indian J Pathol Microbiol 2009, 52(2):171-174.

39. Wu TY, West B, Chen YW, Hergert C: Health beliefs and practices related to breast cancer screening in Filipino, Chinese and Asian-Indian women. Cancer Detect Prev 2006, 30(1):58-66.

40. Blesch KS, Davis F, Kamath SK: A comparison of breast and colon cancer incidence rates among native Asian Indians, US immigrant Asian Indians, and whites. J Am Diet Assoc 1999, 99(10):1275-1277.

41. Chakraborty A, Mishra AK, Soni A, Regina T, Mohil R, Bhatnagar D, Bhatnagar A, Chintamani C, Sharma PC, Saxena S: Vitamin D receptor gene polymorphism(s) and breast cancer risk in north Indians. Cancer Detect Prev 2009, 32(5-6):386-394.

42. Bauer KR, Brown M, Cress RD, Parise CA, Caggiano V: Descriptive analysis of estrogen receptor (ER)-negative, progesterone receptor (PR)negative, and HER2-negative invasive breast cancer, the so-called triple-negative phenotype: a population-based study from the California cancer Registry. Cancer 2007, 109(9):1721-1728.

43. Bertolo C, Guerrero D, Vicente F, Cordoba A, Esteller M, Ropero S, GuillenGrima F, Martinez-Penuela JM, Lera JM: Differences and molecular immunohistochemical parameters in the subtypes of infiltrating ductal breast cancer. Am J Clin Pathol 2008, 130(3):414-424.

44. Del Casar JM, Martin A, Garcia C, Corte MD, Alvarez A, Junquera S, Gonzalez LO, Bongera M, Garcia-Muniz JL, Allende MT, et al::

Characterization of breast cancer subtypes by quantitative assessment of biological parameters: relationship with clinicopathological characteristics, biological features and prognosis. Eur J Obstet Gynecol Reprod Biol 2008, 141(2):147-152.

45. Desmedt C, Haibe-Kains B, Wirapati P, Buyse M, Larsimont D, Bontempi G, Delorenzi M, Piccart M, Sotiriou C: Biological processes associated with breast cancer clinical outcome depend on the molecular subtypes. Clin Cancer Res 2008, 14(16):5158-5165.

46. Hannemann J, Kristel $P$, van Tinteren H, Bontenbal M, van Hoesel QG, Smit WM, Nooij MA, Voest EE, Wall E van der, Hupperets P, et al:: Molecular subtypes of breast cancer and amplification of topoisomerase II alpha: predictive role in dose intensive adjuvant chemotherapy. Br J Cancer 2006, 95(10):1334-1341.
47. Harris LN, Broadwater G, Lin NU, Miron A, Schnitt SJ, Cowan D, Lara J, Bleiweiss I, Berry D, Ellis M, et al:: Molecular subtypes of breast cancer in relation to paclitaxel response and outcomes in women with metastatic disease: results from CALGB 9342. Breast Cancer Res 2006 8(6):R66.

48. Ivshina AV, George J, Senko O, Mow B, Putti TC, Smeds J, Lindahl T, Pawitan Y, Hall P, Nordgren H, et al:: Genetic reclassification of histologic grade delineates new clinical subtypes of breast cancer. Cancer Res 2006, 66(21):10292-10301.

49. Rosenberg LU, Magnusson C, Lindstrom E, Wedren S, Hall P, Dickman PW: Menopausal hormone therapy and other breast cancer risk factors in relation to the risk of different histological subtypes of breast cancer: a case-control study. Breast Cancer Res 2006, 8(1):R11.

50. Ben Hamida A, Labidi IS, Mrad K, Charafe-Jauffret E, Ben Arab S, Esterni B, Xerri L, Viens P, Bertucci F, Birnbaum D, et al:: Markers of subtypes in inflammatory breast cancer studied by immunohistochemistry: prominent expression of P-cadherin. BMC Cancer 2008, 8:28

51. Bertucci F, Finetti P, Rougemont J, Charafe-Jauffret E, Cervera N, Tarpin C, Nguyen C, Xerri L, Houlgatte R, Jacquemier J, et al.: Gene expression profiling identifies molecular subtypes of inflammatory breast cancer. Cancer Res 2005, 65(6):2170-2178.

52. Van Laere SJ, Eynden GG Van den, Auwera I Van der, Vandenberghe M, van Dam P, Van Marck EA, van Golen KL, Vermeulen PB, Dirix LY: Identification of cell-of-origin breast tumor subtypes in inflammatory breast cancer by gene expression profiling. Breast Cancer Res Treat 2006 95(3):243-255.

53. Chan SW, LaVigne KA, Port ER, Fey JV, Brogi E, Borgen PI, Cody HS: Does the benefit of sentinel node frozen section vary between patients with invasive duct, invasive lobular, and favorable histologic subtypes of breast cancer? Ann Surg 2008, 247(1):143-149.

54. Wong SL, Chao C, Edwards MJ, Carlson DJ, Laidley A, Noyes RD, McGlothin T, Ley PB, Tuttle T, Schadt M, et al.: Frequency of sentinel lymph node metastases in patients with favorable breast cancer histologic subtypes. Am J Surg 2002, 184(6):492-498.

55. Dinshaw KA, Sarin R, Budrukkar AN, Shrivastava SK, Deshpande DD, Chinoy RF, Badwe R, Hawaldar R: Safety and feasibility of breast conserving therapy in Indian women: two decades of experience at Tata Memorial Hospital. J Surg Oncol 2006, 94(2):105-113.

56. Vyas JJ, Desai PB, Sampat MB, Shinde SR, Rao DN, Sarkar S, Badwe R, Tiwari J, Koppikar A: Observations on Indian node-negative breast cancer patients: a multivariate analysis. J Surg Oncol 1989, 42(4):256-263.

57. Pestonjamasp PH, Mittra I: Analysis of BRCA1 involvement in breast cancer in Indian women. J Biosci 2000, 25(1):19-23.

58. Saxena S, Chakraborty A, Kaushal M, Kotwal S, Bhatanager D, Mohil RS, Chintamani C, Aggarwal AK, Sharma VK, Sharma PC, et al.: Contribution of germline BRCA1 and BRCA2 sequence alterations to breast cancer in Northern India. BMC Med Genet 2006, 7:75.

59. Saxena S, Szabo Cl, Chopin S, Barjhoux L, Sinilnikova O, Lenoir G, Goldgar DE, Bhatanager D: BRCA1 and BRCA2 in Indian breast cancer patients. Hum Mutat 2002, 20(6):473-474.

60. Keam B, Im SA, Kim HJ, Oh DY, Kim JH, Lee SH, Chie EK, Han W, Kim DW, Moon WK, et al:: Prognostic impact of clinicopathologic parameters in stage II/III breast cancer treated with neoadjuvant docetaxel and doxorubicin chemotherapy: paradoxical features of the triple negative breast cancer. BMC Cancer 2007, 7:203.

Pre-publication history

The pre-publication history for this paper can be accessed here: http://www.biomedcentral.com/1471-2407/10/191/prepub

\section{doi: 10.1186/1471-2407-10-191}

Cite this article as: Kakarala et al., Breast cancer histology and receptor status characterization in Asian Indian and Pakistani women in the U.S. - a SEER analysis BMC Cancer 2010, 10:191 